\title{
Style Action and Emerging-Market Securities Imperfections: An Asean Study
}

\author{
Ashley G Frank
}

Graduate School of Business, University of Durban-Westville

\section{ABSTRACT}

This study is concerned with devising short-term switching strategies to capitalize on abnormal return opportunities by examining the interaction between style action and market phase. Thus it seeks to determine whether styles do better under different market conditions. A total of 288 stocks from five ASEAN countries over an eight-year period comprising four distinct market segments are considered. Market phases are distinguished by recursiveregression estimation while the portfolios are scored by use of a meanvariance/tracking-error methodology. The statistical significance of the performance of each individual style, so rated, is investigated parametrically. The study concludes that value reigns under most market conditions, except for the early bull period where growth investing is superior.

JEL G10

\section{BACKGROUND}

While timing strategies based on size, style and market have long been attractive to investors as potential sources of added value (Banz, 1981; Rosenberg et al., 1985; Fama \& French, 1992a, Chan et al., 1993 and Jegadeesh \& Titman, 1993), the ability to outperform a benchmark by accurately timing these dimensions remains debatable. However, long-term excess return premiums are reportedly associated with one side of each of these three cases: value along the style dimension, small cap along the size dimension and equity among the market choices (Fama \& French, 1992a).

Few academic studies have examined what drives cyclical style return differences or whether and how tactical style allocation can be achieved. Further, many studies fail to account for major factors that hinder the comparability of performance among different time periods. Finally, the role of investment region selection has similarly been neglected. If these factors are taken into account, future rankings of performance might be predicted more accurately. 
Within this context, the purpose of this study is to determine the impact, if any, that growth versus value styles have on the predictability of future performance rankings in the Association of South East Asian Nations (ASEAN) when performance is measured over complete stock market cycles. For the purpose of this study, growth stocks refer to those securities of companies with substantial growth prospects, while value stocks are those stocks which appear to be inexpensive relative to some measure of fundamental value. This general understanding will be translated into empirically determinable benchmarks in the methodology section.

\section{ACADEMIC FOUNDATIONS}

The pattern predictability observed by, among others, Fama \& French (1992a) and Malkiel (1993) contributes to a broad definition of the efficient market. It also impacts the equity style allocation (management) process. Sharpe's (1992) article showed that size and growth-value characteristics can explain a large portion of the returns of an equity portfolio. The bulk of the returns (97 per cent) from a diversified equity portfolio is a function of these factors. This would indicate that the most critical issue for a holder of such a portfolio is the equity style exposure of the portfolio against a broad benchmark index.

The notion that the risk of an equity-style-driven investment process is equal to that of the market, but still able to generate excess returns, troubles some observers. What normally happens is that the portfolio is at a lower risk (beta) level than the market about half of the time and at a higher risk the rest of the time. While these two offset each other, resulting in market-like risk, in the short run the risk of being out of sync with the market is the source of excess returns (Westervelt \& Schwab, 1995).

If the risk of being out of sync with the market is the source of excess returns, then the common approach to portfolio structure, that of equity style neutrality, must be re-examined. This approach ignores the potential gains from equity style management and relies solely on stock selection as a source of excess retums. A fund manager's aggregate portfolio in an equity-style-neutral structure approximately replicates the market by size and industry weights. 


\section{IMPORTANCE OF EQUITY STYLE TIMING}

First Madison Advisors (1995) examined the opportunity to add value through allocation. They found that, over a 15-year period, the opportunity to add value through asset-class allocation was 18.73 per cent. This compared with 15.69 per cent as the opportunity to add value through equity-style allocation within an equity portfolio. Although these resulted from unattainable best-case scenarios, one can see that the magnitude of increased returns from equity-style management rivals that of asset-style allocation in relative importance and opportunity.

Practitioners of equity-style timing believe that splitting the stock universe on the value and growth dimension is a more natural split of the stock universe than any other style definitions, such as beta or size. This is because the differences in returns to these styles are more likely to be driven by economic fundamentals. They believe that business cycles and trends in earnings underpin the differences in returns between the value and growth segments of the stock market and that these fundamental relationships persist (Kao \& Shumaker, 1999).

Because almost any definition of value can be used to outperform an index, it has been argued that value has a positive bias versus growth - on average, about 300 basis points of outperformance and a larger bias for small capitalization stocks (Calderwood, 1995). The value edge differs somewhat by size, index vendor, time horizon and universe used, but it is enduring and is delivered with lower levels of risk than the returns associated with the growth style. Calderwood (1995) concludes that the underlying reasons for value's positive bias are a yield premium, value analysts' reliance on hard data, the phenomenon of mean reversion, and most importantly, what he calls 'mental demons', such as fear of regret.

Indeed, it has often been proposed that value investing produces above average results; that the results are enduring; and that the benefits are obtainable globally (Mitchell, 1995). Certainly, widely displayed biases about wealth work to the advantage of value investors; namely, people overvalue certainty, overreact to big events with small probabilities of occurring and are averse to loss. To this can be added two axioms driving superior performance. First, value is a function of anxiety. Empirical evidence on earnings revisions in the United States and other developed markets shows that the 'domain of potential losses' (negative revisions) is where abnormal returns are earned. Second, mean reversion is strong. Returns on equity in the United States and other markets revert strongly to the mean in relatively short periods of time. These two factors help explain the value advantage which may be documented by showing global 
premiums to value investing over time (Sanders, 1995). Diversification benefits accrue as a bonus because the value premiums between markets are not highly correlated.

However, many investment firms with a growth investing focus have experienced remarkable increases in assets under management during the past 20 years. Evidence suggests that these firms did not sacrifice returns to achieve that asset growth, as they matched or exceeded standard benchmark measures of performance (Hall, 1995). Indeed, it is contended that the business of growth stock investing has involved being at the right place at the right time and being patient in the face of unfavorable developments. Of course, among the primary factors are low turnover, an emphasis on total returns, a focus on noncyclicals and the importance of favourable macroeconomic conditions (Rosenberg, 1995). Still, a widely known fact in the investment community is that growth managers, unlike value managers, tend to outperform their growth benchmarks over time, especially in the area of small cap stocks.

According to research by Trittin (1994) on the performance of institutional money managers tracked by the Frank Russell Company, the average smallcap/growth stock manager outperformed the Russell 2000 Growth Index by about 850 bps a year for the eight-year period that ended on December 31 , 1993. For a shorter time period (five years) and with limited data available, the excess return of the average small-cap/value manager over the Russell 2000 was about 170 bps a year.

Based on historical return data, growth managers' tendency to outperform the passive alternative supports the notion that indexing growth stocks and permanently tilting on value could be suboptimal for equity funds. Hence the overall outcome of this study is to be able to devise short-term switching strategies to capitalize on abnormal return opportunities.

\section{OBJECTIVES}

The objectives of this study were to:

- evaluate variables representing the different styles of value and growth investing;

- consider over eight years of data on 288 stocks from the ASEAN 5 countries;

- construct style portfolios and rebalance them on a monthly basis while calculating retums in local currency and US\$ terms; 
- break the time-frame up into four distinct segments covering an early bull market, a late bull market, a flat market and a bear market, rather than evaluate each styles action over the entire history. By defining time periods on the basis of market cycles, relative portfolio performance is expected to be more consistent over adjacent time periods than when performance is measured arbitrarily over successive calendar quarters or calendar years (Bauman \& Miller, 1994).

The following hypothesis was tested: Style action is cyclical in nature. The hypothesis is concerned with relating the value and growth styles to market direction and seeks to determine whether the styles do better under different market conditions.

\section{RESEARCH METHOD}

Data from the Jardine Fleming Asean Strategy Database was extracted according to constraints of sample size and time frame. Relative return and risk was examined with perfect foresight (i.e., taking a long position in the higher performing portfolio and a short position in the lower returning one). Monthly data was used and where necessary, annual data was converted into a monthly format through a system of time weighting.

Rather than evaluate each style's action over an entire history, the time frame was broken up for analysis into four distinct segments covering an early bull market, a late bull market, a flat market and a bear market. This enabled the situation of style action in the context of market direction, based on the premise that style action is cyclical in nature. Market phase demarcation was achieved by recursive-regression estimation that tests for structural breaks in the trend of the equity market.

\section{SAMPLE}

The study made use of key numbers from over eight years of data on 288 stocks drawn from a Jardine Fleming Strategy Database. This database covers stocks in

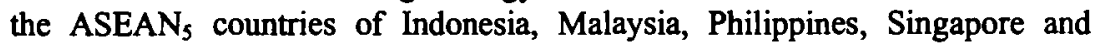
Thailand. The stocks were selected such that each country was represented to at least 50 per cent of its market capitalization and that the total percentage of regional market capitalization referred to, was at least 60 per cent. The obvious attraction of this weighting system is that it reflects the aggregate market. The capitalization-weighted aggregation of all individual securities (often called the market portfolio) must, after adjustment for cross-holdings, equal asset- 
weighted aggregations of all investor portfolios (Umstead, 1988). Thus the performance of the market portfolio always equals the gross performance of investors. It provides a useful performance benchmark, presents a distillation of market-place wisdom, and is the only portfolio that all investors can hold simultaneously.

Table 1 Benchmark coverage snapshot

\begin{tabular}{|c|c|c|}
\hline Country & $\begin{array}{c}\text { No. of Stocks in the } \\
\text { Study }\end{array}$ & $\begin{array}{c}\text { \% of Total Market } \\
\text { Capitalization }\end{array}$ \\
\hline Indonesia & 37 & 62 \\
\hline Malaysia & 89 & 67 \\
\hline Philippines & 46 & 89 \\
\hline Singapore & 50 & 51 \\
\hline Thailand & 66 & 74 \\
\hline Total & 288 & 62 \\
\hline
\end{tabular}

Monthly data was used and where necessary annual data was converted into a monthly format through a process of time-weighting based on trading days. In selecting styles for analysis, due to the possible interplay of small-cap/large-cap or winner/loser effects, only styles that belonged clearly to either value or growth categories were included. Hybrid styles were avoided. Ignoring other screens such as size and quality was expected to restrict the investigation to the value-versus-growth issue only.

A caveat is called for here. The Jardine Fleming ASEAN strategy database is the most comprehensive database, maintained by an international securities house, for the region as a whole. And monthly sorts of its 288 stocks were no easy feat, implying approximately 340704 sorts had to be made in total. However, this means that only one repetition of each market phase was considered. To ensure that externalities were not captured by those phases the recursive regressions that produced each break were compared with accepted industry definitions to ensure their congruency (HSBC, 1994).

\section{DATA COLLECTION AND ANALYSIS}

The specific value styles that were evaluated were PER (Price-Earnings Ratio, both current and forward), PBR (Price-to-Book Ratio, both current and forward), PCFR (Price-to-Cash-Flow Ratio, both current and forward), dividend yield (current and forward) as well as Enterprise Value ${ }^{2}$ to Sales. Current values were calculated using share prices and financial numbers at a common point of observation. In contrast, forward values, rather than using forecasts, were 
calculated using share prices current at the point of observation and financial numbers exactly one calendar year later, this period being the industry norm.

The use of historical actuals rather than forecast figures in the forward calculation was driven by difficulties in obtaining historical consensus figures. Fortunately, as it was possible to define a complete market cycle that ended July 1998, there was no difficulty using actual numbers up to July 1999.

The growth styles calculated were EPS (Earnings Per Share) growth, sustainable growth rate, net profit reinvestment rate and total assets growth, with EPS and total assets growth expressed as Year-on-Year percentage changes. Table 2 gives the definitions used in making both value and growth distinctions.

Portfolios for the individual styles were constructed with perfect foresight and (as required by the MVTE approach) bear-sales were not allowed. The database was thus sorted in ascending order for all value styles (except for dividend yield) and in descending order for all growth styles and the top and bottom quintiles were demarcated. The top quintile $\left(Q_{1}\right)$ is the preferred style end and represents companies with low PER, PBR, PCFR and Enterprise Value to Sales as well as those companies with high EPS growth, sustainable growth, NP investment rates and total assets growth. By contrast, the bottom quintile $\left(Q_{3}\right)$ represents the respective opposites and is the style end to be avoided.

Once the opposing quintiles were demarcated, the average returns of each in both local currency and US\$ terms were calculated. The average returns of the top quintile were calculated in absolute and relative terms, the latter with reference to the benchmark, given by the average over the entire database.

To make the whole exercise as dynamic as possible the style portfolios were rebalanced every month.

In order to incorporate both return and risk aspects of style effectiveness under various market conditions, it was thought applicable to describe style effectiveness by a single number. To do this relative scores were calculated on three variables, all in US\$ terms:

- The cumulative returns of the top quintile relative to the benchmark;

- The cumulative returns of the top quintile relative to the bottom quintile and

- The standard deviation of the average returns of the top quintile. 
Table 2 How screen styles were identified

\begin{tabular}{|c|c|c|c|}
\hline Ratio & $\begin{array}{l}\text { Definition } \\
\text { Employed } \\
\end{array}$ & $\begin{array}{c}\text { Value } \\
\text { Characteristic } \\
\end{array}$ & $\begin{array}{c}\text { Growth } \\
\text { Characteristic } \\
\end{array}$ \\
\hline PER & Share price over EPS & $\begin{array}{l}\text { Must have been less } \\
\text { than } 40 \% \text { of the } \\
\text { average market } P E\end{array}$ & $\begin{array}{l}\text { Must have been } \\
\text { more than } 40 \% \text { of } \\
\text { the average market } \\
\text { PE }\end{array}$ \\
\hline PBR & $\begin{array}{l}\text { Share price over } \\
\text { shareholders equity per } \\
\text { share }\end{array}$ & $\begin{array}{l}\text { Price }<\text { Two-thirds of } \\
\text { book value }\end{array}$ & $\begin{array}{l}\text { Price }>\text { Two-thirds } \\
\text { of book value }\end{array}$ \\
\hline PCFR & $\begin{array}{l}\text { Share price over cash } \\
\text { flow per share based on } \\
\text { EPS plus depreciation } \\
\text { and amortisation minus } \\
\text { monetary gain/loss and } \\
\text { foreign exchange } \\
\text { gain/loss per share for } \\
\text { the fiscal year }\end{array}$ & $\begin{array}{l}\text { Must have been less } \\
\text { than } 20 \% \text { of the } \\
\text { average market PCFR }\end{array}$ & $\begin{array}{l}\text { Must have been } \\
\text { more than } 20 \% \text { of } \\
\text { the average market } \\
\text { PCFR }\end{array}$ \\
\hline $\begin{array}{l}\text { Dividend } \\
\text { Yield }\end{array}$ & $\begin{array}{l}\text { Dividend on the main } \\
\text { type of share multiplied } \\
\text { by the grossing up } \\
\text { factor, expressed as a } \\
\text { percentage of the price } \\
\text { of the main type of } \\
\text { share }\end{array}$ & $\begin{array}{l}\text { Dividend Yield } \\
\text { greater than Two- } \\
\text { thirds of the AAA } \\
\text { Corporate Bond Yield }\end{array}$ & $\begin{array}{l}\text { Dividend Yield less } \\
\text { than average } \\
\text { corporate bond } \\
\text { yield. }\end{array}$ \\
\hline $\begin{array}{l}\text { Enterprise } \\
\text { Value to } \\
\text { Sales }\end{array}$ & $\begin{array}{l}\text { Market capitalization } \\
\text { plus latest available net } \\
\text { debt over sales for } \\
\text { fiscal year }\end{array}$ & $\begin{array}{l}\text { Must have been less } \\
\text { than } 20 \% \text { of average } \\
\text { market EV/S with } \\
\text { debt being less than } \\
\text { twice net current } \\
\text { assets }\end{array}$ & $\begin{array}{l}\text { Must have been } \\
\text { more than } 20 \% \text { of } \\
\text { average market } \\
\text { EV/S with debt } \\
\text { more than twice net } \\
\text { current assets } \\
\end{array}$ \\
\hline EPS Growth & $\begin{array}{l}\text { Year on Year growth in } \\
\text { Earnings per Share }\end{array}$ & $\begin{array}{l}\text { Growth greater than } \\
7 \%\end{array}$ & $\begin{array}{l}\text { Growth greater than } \\
\text { twice inflation rate }\end{array}$ \\
\hline $\begin{array}{l}\text { Sustainable } \\
\text { Growth Rate }\end{array}$ & Dividend growth rate & $\begin{array}{l}\text { Growth equal or less } \\
\text { than overall market } \\
\text { growth }\end{array}$ & $\begin{array}{l}\text { Growth greater than } \\
\text { overall market } \\
\text { growth }\end{array}$ \\
\hline $\begin{array}{l}\text { Net Profit } \\
\text { Reinvestment } \\
\text { Rate } \\
\end{array}$ & $\begin{array}{l}\text { Rate of growth in } \\
\text { reinvested profit }\end{array}$ & $\begin{array}{l}\text { Growth rate less than } \\
\text { dividend growth rate }\end{array}$ & $\begin{array}{l}\text { Growth rate greater } \\
\text { than dividend } \\
\text { growth rate }\end{array}$ \\
\hline $\begin{array}{l}\text { Total Assets } \\
\text { Growth }\end{array}$ & $\begin{array}{l}\text { Growth rate of sum of } \\
\text { current and fixed assets }\end{array}$ & $\begin{array}{l}\text { Growth rate > rate of } \\
\text { growth of liabilities } \\
\text { with a debt-equity } \\
\text { ratio of } 1\end{array}$ & $\begin{array}{l}\text { Growth rate }< \\
\text { liability growth rate, } \\
\text { debt-equity ratio } \\
\text { greater than } 1\end{array}$ \\
\hline
\end{tabular}

Adapted with reference to Amott \& Copeland (1985) \& Forsythe (1995) 
Relative scoring was done for the first two variables (measuring returns) by setting a maximum of the range (across different styles) to 100 and the minimum to 0 . For the third variable, which reflects the degree of risk (of which a greater quantity is obviously less desirable), the scoring system was reversed with the minimum standard deviation of the range fetching a score of 100 and the maximum a score of 0 . These are reported in Tables 3,4 and 5 .

Next, the relative score on each variable was weighted (50 per cent for the first and 25 per cent for the second and third) to derive a composite styleeffectiveness score. One such number was computed for each style in every phase. The composite is tilted in favour of return, with the two variables measuring relative retums holding a 75 per cent weight while the risk variable carries a weight of only 25 per cent. This was based on the assumption that most investors see (high) return as a necessity and (low) volatility as desirable.

Emerging markets in general and Asian equities in particular attract investors who wish to diversify out of their home markets where earnings growth prospects are by and large anemic. For this reason, return rather than risk becomes the paramount consideration ${ }^{3}$, with the risk element already being addressed through abundant exposure to developed country investments. This keeps the overall volatility of their global portfolio at a comfortably low level.

A dominant weight for the retum parameter also enables it to behave more like a filter, helping to screen out styles that deliver poor relative returns but exhibiting low risk. The composite scores obtained after suitably weighting the individual variable scores were expressed on a range from 0 to 100 , with these magnitudes being directly proportional to their effectiveness. Thus a higher score signifies that a style is more useful.

\section{APPROACH FOR HYPOTHESIS TESTING}

Weekly returns in US\$ from the Composite or All Share Indices for all five countries were used to identify market phase turning points. Log values of these returns were put through a recursive regression estimation analysis to determine at which point the F-statistic was greater than the market threshold level. For at these points there is confidence that a statistical break point has been reached. Weekly returns for these Indices were obtained from the financial markets news service Bloombergs, who in turn receive the numbers directly from each market's news division.

However, as a holistic picture of the ASEAN region was desired, all the values needed to be distilled to arrive at one common set of phase periods. Thus 
statistical averaging techniques were used here. This resulted in the following time frames being set:

- $\quad$ Early Bull: December 1990 to December 1993;

- $\quad$ Flat Market: December 1993 to November 1995;

- Late Bull: November 1995 to June 1997;

- $\quad$ Bear Market: June 1997 to July 1998.

Figure I shows the respective periods outlined on the benchmark index (the portfolio of 288 securities). The movement during the early bull phase shows an increase in value by 68 per cent. That during the flat period there is 98 per cent confidence that the market remained 2.77 standard errors away from the period's mean of US\$ 245.63 , implies a narrow range of only US\$ 5.51 . This quite sufficiently justifies that period being defined as flat. The bear market is characterized by a decline from US\$285.68 to US $\$ 143.35$ a loss of 50 per cent. When using recursive regressions, there is a possibility that the null would be rejected not only at the time of the break, but also for observations just before and after it. Thus particular care was taken to ensure that each phase delineation was well within industry definitions advanced for them (HSBC, 1994) and so were accepted.

Placing the analysis into these four distinct market phases enables style action to be understood in the context of market direction, based on the premise to be tested, that style action is cyclical in nature. Indices were computed to track the average returns of the top and bottom quintiles in local currency as well as US\$ terms. From these, the cumulative returns of opposite style ends were calculated. A similar calculation was done for the relative (to benchmark) returns of the top quintile. In addition to making these return calculations, the standard deviation of average returns of the top quintile as a measure of risk or volatility was found. 
Figure 1 Statistical break points, benchmarck index

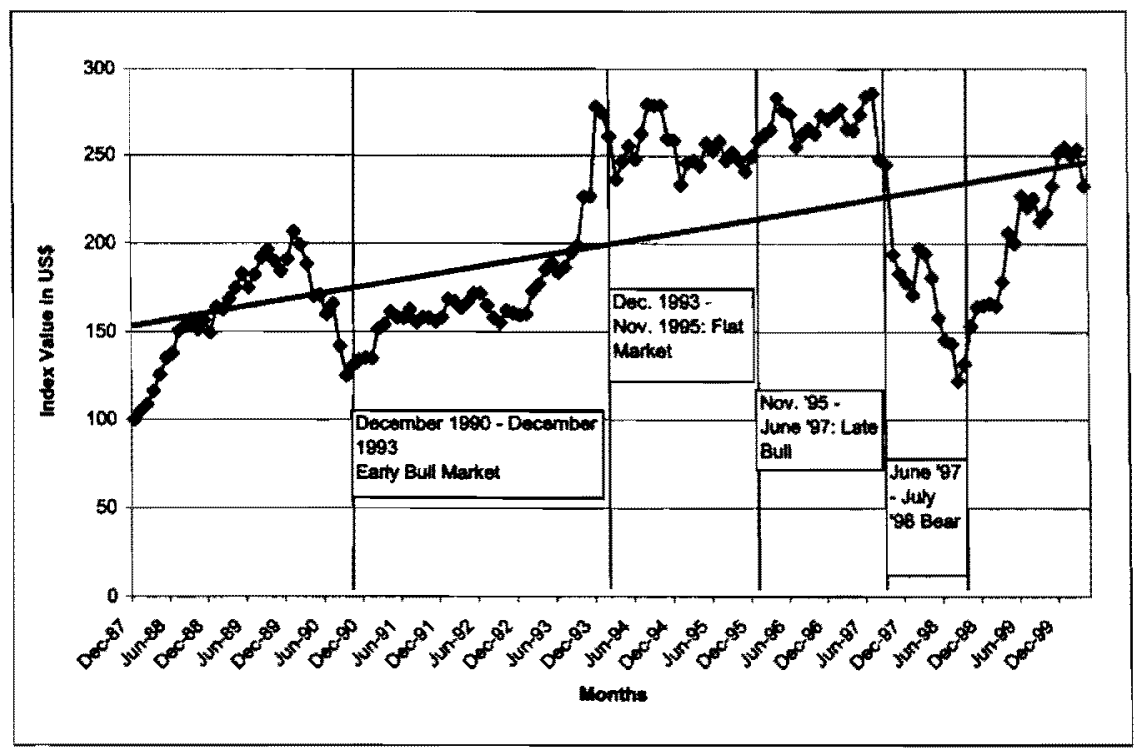

The starting point was the argument that the standard mean-variance (MV) utility function is inadequate for investors concerned about portfolios that diverge from the benchmark. For them, the utility function needs to be modified to include dissatisfaction with deviations from that benchmark. One such modification is the addition of tracking error as a parameter in the utility function, that is:

Maximize $U(P)=\operatorname{ExpRet}(P)-\frac{[\operatorname{ExpRisk}(P)]^{2}}{r t}-\frac{[\operatorname{Exp} T E(P)]^{2}}{t e t}$

subject to:

$\Sigma P_{i}=1 ; \quad P_{i} \geq 0$ for all $i$

where:

$\operatorname{ExpRet}(P)=$ recent expected return of the portfolio

$\operatorname{ExpRisk}(P)=$ recent expected standard deviation of portfolio returns

$\operatorname{Exp} T E(P)=$ percent expected tracking error of portfolio returns

$r t \quad=$ risk tolerance

tet = tracking-error tolerance

$P_{i} \quad=$ proportion of the portfolio allocated to asset $i$. 
Using this new utility function, the portfolio optimization process seeks out portfolios with high-expected retums and low portfolio volatility on an absolute basis (the MV part) as well as relative to a benchmark (the TE part). Investors may define the relative importance of these three goals when they assign risktolerance and tracking-error tolerance. In this study the formula will be referred to as the mean-variance/tracking-error (MVTE) utility function.

The study made use of this extended Markowitz model of mean-variance. Analysis of this utility function ensures that its set of efficient portfolios includes the mean-variance efficient set, a mean-tracking error efficient set and all convex combinations of these two sets. Optimization of this utility function may find solutions that investors will actually use (Chow, 1995).

Market cycles together with the MVTE approach were used to account for or neutralize differences in portfolio risks. It thus avoided the use of risk-adjusted returns such as the Sharpe, Treynor and Jensen statistics that are alleged to be subject to statistical biases, nonstationarity and other measurement problems ${ }^{4}$.

Although only one hypothesis, that style action is cyclical in nature, was to be investigated, it was envisaged that many observations about the behaviour of the different styles under the varied market phases would come to the fore. In synthesizing these results it would be important that these too be subject to statistical testing. As each market phase was seen as a separate and independent sample it was possible to arrive at a mean MVTE score for the phase as a whole. Coupled with the relatively small $(\mathrm{N}=13)$ number of style effectiveness scores for each phase and the fact that the sample deviation stood in as a population deviation, a parametric test of significance was thought to be appropriate. The results of this analysis (reported as Appendix A, at the end of the paper) should show whether the assigned MVTE performance not only differed but did so statistically, from what would have been expected. A significance level of 5 per cent was judged to be prudent.

\section{SYNTHESIS AND DISCUSSION}

Figure 2 shows the cyclical action of the growth styles (EPS growth, total assets growth, NP reinvestment rate, sustainable growth rate) in the basket. Clearly, the growth approaches yield the best results when the bull market is in its infancy. The rise in the equity market at this time, occurs in the absence of economic or eamings growth but as a result of falling bond yields that improve relative valuation. Because participants are acting on prospects for profit recovery, rather than on hard data, the growth style is favoured. The effectiveness of the leading growth style declines substantially as the bull 
market matures; the sustainable growth rate and NP reinvestment rate styles are marginal exceptions to this. These, although peaking later in the bull cycle, post return and overall scores that are modest and not statistically significant as Appendix A shows. Hence the first observation arrived at, is that Growth wins at the beginning of the bull cycle.

\section{Figure 2 The growth styles}

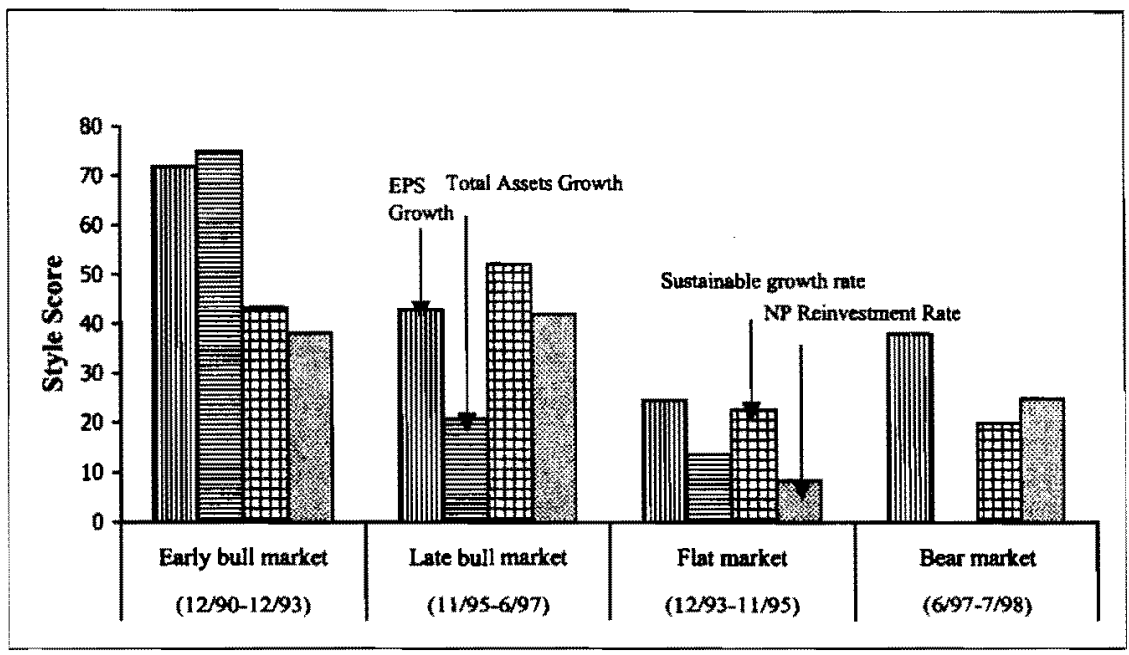

Intemational investors looking for growth generally make their debut in the early stages of equity bull cycles. The entry of these investors who are diversifying out of slow-growing home markets is a possible reason why growth approaches perform so well in this period. The changing supply/demand balance possibly reflects the high cash and near-cash holdings of participants at this early stage. Also, there tends to be an increase in the incidence of positive earnings surprises in this period which produce fluctuations in value parameters such as PER and PCFR that have earnings-driven denominators. This tends to focus the spotlight on growth, which is identified as the prime mover of share price performance, while value fades to the background. Later on, as the bull market matures, earnings surprises become fewer, making the value parameters more stable. This process leads to a progressive decline in the effectiveness of the growth styles. It is thus also possible to deduce that earnings surprises, often found at the start of the bull phase, support growth approaches. 
Not all the growth styles examined in the basket performed equally well. The styles worth following are EPS growth and total assets growth, which even then were only statistically significant during the early bull phase. The scores of the other two styles (i.e., sustainable growth rate and NP reinvestment rate) failed to rise above the mediocre. As these styles are most suitable for investors with long-term horizons, their inferior performance may suggest that most ASEAN equity investors have short-term orientations. A further observation is thus that Earnings-Per-Share and Total Assets Growth are the most effective growth styles.

A flat market is the worst platform for a growth strategy. All the growth styles post their lowest scores in that phase of market. Common sense dictates that as value is relatively abundant and growth scarce in a declining market, growth styles may be expected to deliver their best performances in a bear market. Surprisingly, this expectation was belied by the results. In fact, growth approaches exhibited their peak performances in the early stages of a bull market. This is possibly the result of a delayed recognition of the importance of growth, and investor uncertainty about the sustainability of growth patterns in a general climate of bearishness.

Growth styles, as shown in Table 3, are at their least volatile in a bear market. While returns from growth investing do peak in the early stages of a bull market, these gains are accompanied by increased volatility.

Of the growth styles, the NP reinvestment rate and sustainable growth rate are markedly less risky than EPS growth and total assets growth in a young bull market. A positively sloped yield curve reduces the discount rate causing eamings revisions to be rife in this period. However, because their impact on the sustainable growth rate and NP reinvestment rate is both diluted and delayed this may explain their lower volatility.

As the bull market ages, earnings flux abates and is replaced by its trickle-down effects, operating with a lag, on the sustainable growth rate and the NP reinvestment rate. This results in a trade-off between (low) risk and (high) return; price performance for these styles (sustainable growth and NP reinvestment) peaks late in the bull cycle and volatility registers a corresponding rise. Conversely, for EPS and total assets growth, risk drops in the second half of the bull cycle, but with it does relative return. 


\section{Table 3 Volatility of growth styles}

\begin{tabular}{|l|c|c|c|c|}
\hline \multirow{2}{*}{ Style } & \multicolumn{4}{|c|}{ Market Phase } \\
\cline { 2 - 5 } & Early Bull & Late Bull & Flat & Bear \\
\hline EPS growth & 23 & 62 & 0 & 100 \\
\hline Sustainable growth rate & 68 & 50 & 23 & 72 \\
\hline Total assets growth & 0 & 44 & 28 & NA \\
\hline NP reinvestment rate & 69 & 0 & 25 & 60 \\
\hline
\end{tabular}

Note: Scores range from 0 (maximum risk) to 100 (minimum risk) on a standard deviation basis.

Figure 3 shows those value styles that made use of current rather than forward financial numbers. As with the growth styles, it was discovered that the effectiveness of the value styles varies depending on the overall direction of the market. Mature bull markets or flat markets appear to provide the best platforms for value-oriented investment strategies.

$\mathrm{PER}_{\mathrm{c}}$ is the top pick among the value (current) ratios, showing statistical significance in all but the bear phase. It proved to be more effective than any other value (current) style in late bull and flat markets, with performance peaking at the top of a bull market. Its dominance among the value (current) styles is probably due to its popularity among the investment community. As mentioned in the previous section, eamings surprises tend to reduce in number and magnitude in late bull and flat markets, with the market seeking confirmation of a recovery, resulting in greater stability of value parameters such as PER and PCFR. This could explain the more general shift to value evident under these conditions. It is thus possible to observe that PriceEarnings-Ratios are the top value (current) style. 
Figure 3 The value (current) styles

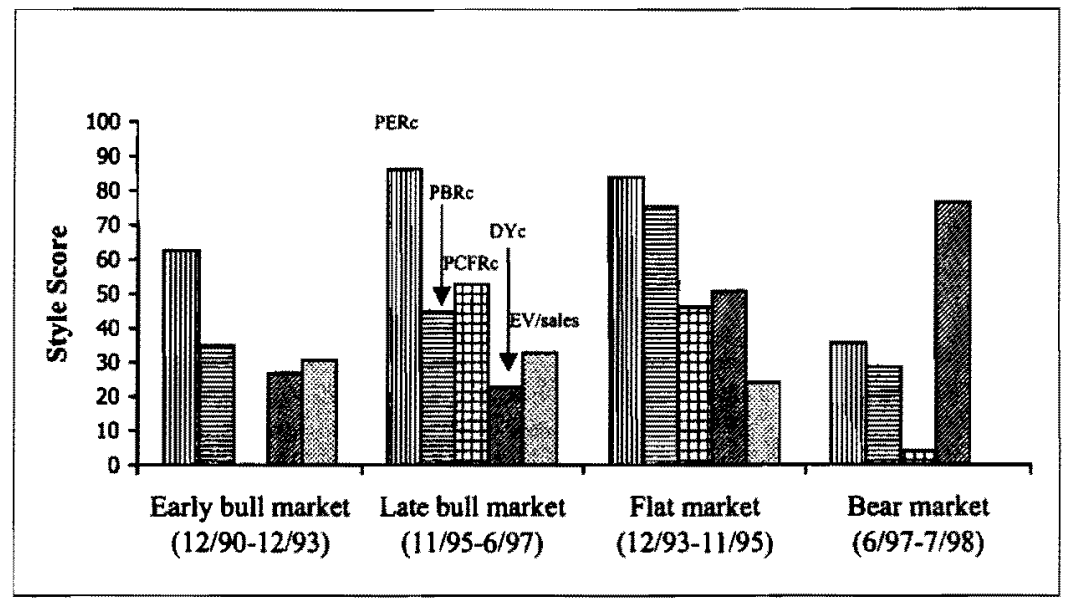

The least risky styles in the value (current) basket are $\mathrm{PCFR}_{\mathrm{c}}$ and $D Y_{\mathrm{c}}$ in mature bull and flat markets, though their overall performance on an MVTE basis was not statistically significant. However, PER, the winner under these conditions on pure return considerations, is more volatile. Its risk may be low in the early stages of a bull market, but there, the growth styles perform better on renum. However, although its volatility is highest in a bear market, this is true for most other styles as well, and this is therefore no exception.

Table 4 Volatility of value (current) styles

\begin{tabular}{|l|c|c|c|c|}
\hline \multirow{2}{*}{ Style } & \multicolumn{4}{|c|}{ Market Phase } \\
\cline { 2 - 5 } & Early bull & Late bull & Flat & Bear \\
\hline PER $_{c}$ & 79 & 51 & 35 & 0 \\
\hline PBR $_{c}$ & 54 & 62 & 46 & 14 \\
\hline PCFR $_{c}$ & 0 & 100 & 62 & 11 \\
\hline DY $_{c}$ & 68 & 89 & 46 & 25 \\
\hline
\end{tabular}

Note: Scores range from 0 (maximum risk) to 100 (minimum risk) on a standard deviation basis. 
The increased volatility of all value styles under bearish conditions may be the result of the poor predictability of earnings. The contrast with growth styles is most pronounced in a bear market as they exhibit minimum risk then. An interesting observation is that PER $_{c}$ (which is directly driven by earnings and is highly sensitive to changes in depreciation) exhibits greater volatility than PCFR $_{c}$ (which is depreciation-independent). The latter ratio is comparatively more stable in mature bull, flat and bear markets. Depreciation charges tend to peak in a bear market at the same time that earnings are declining, making depreciation a big swing factor. This could explain why PER $_{c}$ is at the bottom of the table (having the highest risk) in a bear market.

In a bear market, as bond yields rise and growth and eamings fall, the baton in the value (current) basket passes from $P R_{c}$ to $D Y_{c}$. This style produces best results in this type of market when measured by relative performance but fails to offer less risk than the growth styles. However, it is still the least risky value (current) style, which provides greater motivation for preferring it to other value approaches in a declining market. $\mathrm{DY}_{\mathrm{c}}$ volatility is lowest in a mature market, although relative returns are also weak, causing this style to lag behind PER.

Thus a bear market provides the best context for a surge in the effectiveness of the dividend-yield style, when it becomes the only style in its class to show a statistically significant performance. This may be a function of general riskaversion triggered off by a deteriorating environment and a reflection of the higher value placed on payout by the investor. Generally, there is a higher standard deviation of retums when both bond yields rise and growth and earnings fall. The risk/return ratio rises as the outcomes become less certain. Viewed another way, differences in intrinsic dividend-payout potential come to the fore and become emphasized by investors when all stock prices are equally and indiscriminately under pressure.

Another reason for the superior performance of dividend yield is the tendency of companies' management to fix the nominal dividend rate rather than the payout ratio in a downtum. Such a stable dividend policy is seen as signaling strength to the market. The certainty of holding the dividend rate constant in the face of an earnings decline naturally boosts the payout ratio and puts more cash in the hands of shareholders at a time when cash carries a premium. Thus it is possible to deduce that Current Dividend Yield performs better than Current Price-Earnings-Ratios in a bear market.

The performance of enterprise value to sales is inferior in all market situations: rising, flat or declining. The denominator in this ratio has a lower correlation with earnings than is true of other value styles and the leverage insensitivity implicit in the numerator probably makes this style a poor polariser of returns. 
While risk is lower for this style in all kinds of markets, it cannot compete on retum and hence cannot be seen as a serious alternative. Thus it is observed that Enterprise value to sales is not very useful

A more structural reason underlying the inferior performance of enterprise value to sales may be the virtual absence of strong (local) brand recognition in the ASEAN. The ratio is best applied to companies with strong corporate or product brand equity. For these companies small differences in the enterprise value-tosales ratio may mean large differences in earnings and share-price performance. Most businesses in the ASEAN produce commoditized rather than branded products, hence this style does not work very well.

The Value (forward) Styles shown in Figure 4 were made up of value styles that used one-year forward financial numbers. Most of the performance patterns observed with respect to the current styles also hold good for this group. For example, the effectiveness of $\mathrm{PER}_{\mathrm{f}}$ and PCFR $\mathrm{f}$ peaks in a late bull market and that of $P_{B R}$ peaks in a flat one, the only times these styles become statistically significant. However, the effectiveness of $D Y_{f}$, while still high in a bear market, is bettered, albeit marginally, by its own performance in a trendless market.

The dominance of PER, evident among the value (current) set of styles, was not reflected in this sample. While PER $_{c}$ dominated both flat and mature bull markets among the value (current) styles, on a forward basis, it was PCFR that performed best in a mature bull context and $P_{B R}$ in a flat market. In mature bull markets and early bear markets, the peaking of the investment boom drives depreciation upward. PER is subject to distortion by depreciation but cash flows are immune as the charges are added back in the cash flows. For this reason (and the fact that equity prices lag eamings growth), PCFR $_{f}$ outperforms PER in a mature bull market. The former is also the best style in this class in the early stages of a bull market. Overall, $\mathrm{PCFR}_{f}$ is a very useful style in a mature bull market as it combines high returns with low risk. It is thus observed that forward Price-to-Cash-Flow-Ratios and Price-to-Book-Ratios are most effective in mature bull markets and flat markets respectively. 
Figure 4 Style scores

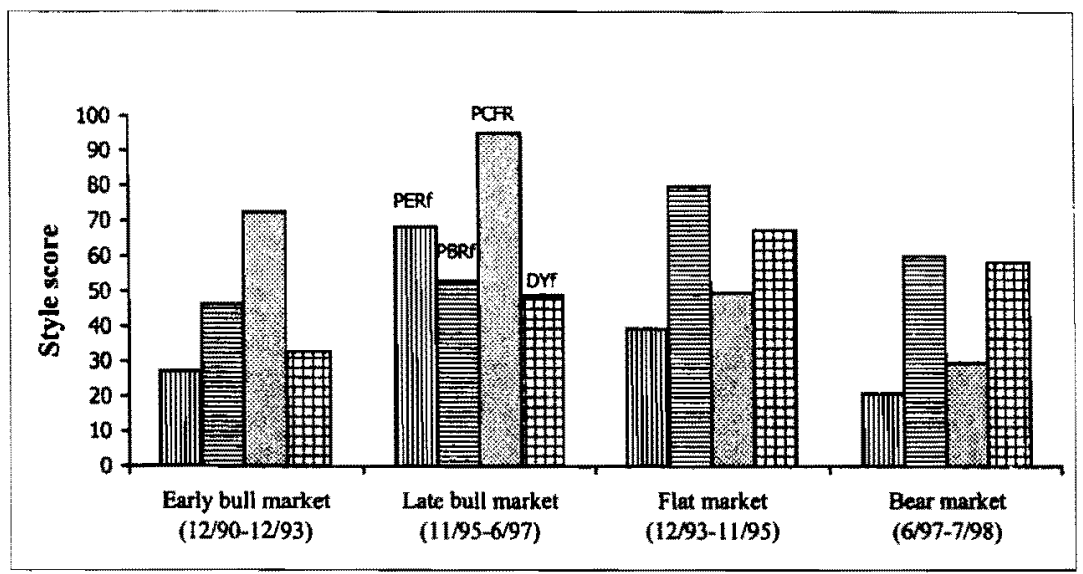

The bear market also shows diversion with $\mathrm{PBR}_{\mathrm{f}}$ doing marginally better than $D Y_{f}$ to claim the most effective spot. Although dividend yield continues to be an important consideration, investors in a bear market also assess company survivability and $\mathrm{PBR}_{\boldsymbol{f}}$ proves to be a better measure of this, as it factors in capital dilution arising from future earnings shocks. It was, therefore, also observed that forward Price-to-Book-Ratios also do well in a bear market.

Examining the risk profiles of the various classes (current and forward) also leads to interesting conclusions. Tables 4 and 5 show the relative scores of each style. These are relative to the scores of the other styles in the same period and range from a minimum of 0 (indicating high volatility) to a maximum of 100 (signifying low volatility). In most cases, the value (forward) styles score higher than their value (current) cousins. The expectations where the converse is true are for PBR in bear markets, PCFR in mature bull and flat markets and dividend yield in young bull markets. 
Table 5 Volatility of value (forward) styles

\begin{tabular}{|c|c|c|c|c|}
\hline \multirow{2}{*}{ Style } & \multicolumn{4}{|c|}{ Market Phases } \\
\cline { 2 - 5 } & Early bull & Late bull & Flat & Bear \\
\hline PER $_{\mathrm{f}}$ & 100 & 68 & 100 & 14 \\
\hline PBR $_{\mathrm{f}}$ & 74 & 68 & 50 & 3 \\
\hline PCFR $_{\mathrm{f}}$ & 74 & 95 & 37 & 35 \\
\hline DY $_{\mathrm{f}}$ & 63 & 92 & 56 & 38 \\
\hline
\end{tabular}

Note: Scores range from 0 (maximum risk) to 100 (minimum risk) on a standard deviation basis.

The value (forward) styles incorporate forward eamings numbers and for that reason is less susceptible to earnings surprises (positive or negative). In contrast the value (current) styles are more likely to be affected by earnings surprises and higher volatility in valuation parameters (PER, PCFR etc.) translate into higher volatility for share prices. Thus it is possible to conclude that value (forward) is generally lower risk than value (current).

Scanning Tables 4 and 5 to spot extremely low or high scores on risk may also be useful. Using discretion and taking scores below 15 and those above 85 as being extremely low and high respectively, it can be seen that $\mathrm{PER}_{\mathrm{f}}$ offers very low volatility in early bull and flat markets; the same being true of PCFR and both $D Y_{c}$ and $D Y_{f}$ in late bull markets. The opposite i.e., very high volatility is associated with $\mathrm{PER}_{c}, \mathrm{PER}_{\mathrm{f}}, \mathrm{PBR}_{\mathrm{c}}, \mathrm{PBR}_{\mathrm{f}}$ and $\mathrm{PCFR}_{\mathrm{c}}$ in declining markets.

\section{CONCLUSION AND RECOMMENDATIONS}

Since the study indicates that style effectiveness has a significant cyclical component, it follows that a sound rotational strategy would reward investment managers. During a declining market they would be advised to use a high dividend yield $\left(\mathrm{DY}_{\mathrm{c}}\right)$ strategy. Although this strategy is marginally riskier than a high $D Y_{f}$ strategy, it has outperformed all other styles with regard to relative retums ( 50 per cent for $Q_{1}$ over the benchmark and 18 per cent over $Q_{s}$ in US $\$$ terms) on a cumulative basis.

However, managers should note that returns in absolute terms for this style (and every other style in the basket) are negative during declining markets.

$\mathrm{PBR}_{\boldsymbol{f}}$ also stands out on a relative-performance basis in a bear market because it has a considerably less negative $Q_{1}$ return than the other styles. While it is inferior to $\mathrm{DY}_{\mathrm{c}}$ it still outperformed the rest of the field. In a bear market, 
investor concerns centre on company survivability, and attention shifts from the income statement (earnings and cash flows) to the balance sheet (equity).

$\mathrm{PBR}_{f}$ works well in particular because, by incorporating forward earnings, it takes into account future dilution of equity (and potential need for recapitalization).

Finally, $D Y_{\mathrm{f}}$ is almost as good as $\mathrm{PBR}_{\mathrm{f}}$, superior $\left(\mathrm{Q}_{1}-\mathrm{Q}_{5}\right)$ returns and a lower standard deviation of $Q_{1}$ returns nearly make up for the edge that $\mathrm{PBR}_{\mathrm{f}}$ has with respect to $\left(Q_{1}\right.$-benchmark) returns.

When evidence of a market turnaround arrives and a bull market gets underway, it is time to switch to a growth-oriented strategy. EPS growth and total assets growth are the best bets in the early stages of a rising market. While the latter approach has a marginally higher effectiveness score, the former is less volatile.

High EPS growth stocks $\left(Q_{1}\right)$ have returned 105 per cent relative to the benchmark and 391 per cent relative to low EPS growth stocks $\left(Q_{s}\right)$ in the past on a cumulative basis.

PCFR $_{\mathrm{f}}$ appears to deliver an outstanding performance in the later stages of a bull market. $P_{E R}$ is a close second. Both these findings are statistically significant at the 95 per cent confidence level. In the period of the study categorized as a late bull market, low PCFR stocks $\left(Q_{1}\right)$ gave returns of 76 per cent over the benchmark and 382 per cent over $Q_{5}$. Also, a PCFR strategy comes with the bonus of extra low volatility; the standard deviation of returns was the lowest for this style.

In a trendless market, both $\mathrm{PER}_{\mathrm{c}}$ and $\mathrm{PBR}_{\mathrm{f}}$ appear to work satisfactorily. In the study, the former gave higher retums ( 55 per cent over the benchmark and 82 per cent over $Q_{5}$ ) than the latter ( 49 per cent over the benchmark and 72 per cent over $\left.Q_{s}\right)$, but the latter was less volatile.

\section{IMPLICATIONS FOR FURTHER RESEARCH}

The hypothesis advanced in this particular study was that "Style action is cyclical in nature". The previous sections have presented evidence that the effectiveness of the various styles and classes do vary depending on the overall direction of the market. The hypothesis could therefore not be rejected. However, many valuable observations relating to the relative action of the particular styles have been uncovered. Individual analysis of each of these, 
while beyond the mandate of this study, seems a necessary and fertile area for ongoing research.

\section{ENDNOTES}

1 One should not bet against the market portfolio without a strong conviction that the collective thinking of millions of investors is wrong

2 Defined as market capitalization plus latest available net debt.

3 This is congruent with the views expressed by Solnik (1988), Kaplanis \& Schaefer (1988) and Eun \& Resnick (1989) who showed that the standard deviation for the US equity market was in fact less than that of other market indices when the deviation of returns was calculated in the local currency. When the effect of exchange risk was taken into account, the higher risk of foreign markets became even more pronounced.

4 Bauman \& Miller (1994), Fama \& French (1992b), Friend \& Blume (1970), Klemkosky (1973) and Roll $(1978,1980,1981)$ all discuss these deficiencies. 


\section{APPENDIX A}

Significance tests for MVTE scores

\begin{tabular}{|l|c|c|c|c|}
\hline \multirow{2}{*}{ Style } & \multicolumn{4}{|c|}{ Market Phase } \\
\cline { 2 - 5 } & Early Bull & Late Bull & Flat & Bear \\
\hline EPS growth & $72^{*}$ & 43 & 25 & 38 \\
\hline Total assets growth rate & $75^{*}$ & 21 & 14 & 0 \\
\hline Sustainable Growth Rate & 43 & 52 & 23 & 20 \\
\hline NP reinvestment Rate & 38 & 42 & 9 & 25 \\
\hline PERc & $63^{*}$ & $86^{*}$ & $84^{*}$ & 36 \\
\hline PBRc & 35 & 45 & $75^{*}$ & 28 \\
\hline PCFRc & 0 & 53 & 46 & 3 \\
\hline Dyc & 27 & 23 & 51 & $76^{*}$ \\
\hline EV/Sales & 31 & 33 & 24 & 0 \\
\hline PERf & 27 & $68^{*}$ & 39 & 21 \\
\hline PBRf & 46 & 53 & $80^{*}$ & $60^{*}$ \\
\hline PCFRf & $72^{*}$ & $95^{*}$ & 50 & 30 \\
\hline Dyf & 33 & 49 & $68^{*}$ & $58^{*}$ \\
\hline Mean Score & 43 & 51 & 45 & 30 \\
\hline Std. Dev. & 22 & 22 & 26 & 24 \\
\hline Note:
\end{tabular}

Note: * indicates performance that is statistically significant at a 95 per cent level of confidence. 


\section{REFERENCES}

1 ARNOTT, R.D. \& COPELAND, W.A. (1985) "The Business Cycle and Security Selection", Financial Analysts Journal, Vol. 41(2): 26-32.

2 BANZ, R.W. (1981) "The Relationship Between Return and Market Value of Common Stock", Journal of Financial Economics, Vol. 9(1): 318.

3 BAUMAN, W.S. \& MILLER, R.E. (1994) "Can Managed Portfolio Performance be Predicted", The Journal of Portfolio Management, Vol. 20(4): $31-40$.

4 CALDERWOOD, S. (1995) "The Positive Bias for Value Investors in U.S. Equities" in Squires, J.R. (ed.) Value and Growth Styles in Equity Investing, ICFA Continuing Education Series, Charlottesville, VA: Association for Investment Management \& Research.

5 CHAN, L.K.C., HAMAO, Y. \& LAKONISHOK, J. (1993) "Fundamentals and Stock Returns in Japan", Journal of Finance, 65(5): 1739-64.

6 CHOW, G. (1995) "Portfolio Selection Based on Return, Risk and Relative Performance" Financial Analysts Journal, 51(2): 54-60.

7 COOTNER, P. (1964) "The Random Character of Stock Market Prices", Cambridge, Mass: The MIT Press.

8 EUN, C. \& RESNICK, B. (1989) "Exchange Rate Uncertainty, Forward Contracts and International Portfolio Selection", Journal of Finance, 44(3): 234-45.

9 FAMA, E.F. \& FRENCH, K.R. (1992a) "The Cross-Section of Expected Stock Retums", Journal of Finance, 47(2): 427-65.

10 FAMA, E.F. \& FRENCH, K.R. (1992b) "The Economic Fundamentals of Size and Book-to-Market Equity", Working paper, No. 361: Graduate School of Business, University of Chicago.

11 FIRST MADISON ADVISORS (1995) "The Importance of Style Allocation", Madison, WI: First Madison Advisors.

12 FORSYTHE, G.J. (1995) "How Does Stock Selection Criteria Performance Vary across Investment Style Universes", in Klein, R.A. \& Lederman, J. (eds.) Equity Style Management: Evaluating and Selecting Investment Styles. Burr Ridge, IL: Irwin Professional Publishing.

13 FRIEND, I. \& BLUME, M. (1970) "Measurement of Portfolio Performance under Uncertainty", American Economic Review, Vol. 60(3): 561-75.

14 HALL, J. P. III (1995) "An Approach to Growth Investing" in Squires, J.R. (ed.), Value and Growth Styles in Equity Investing, ICFA Continuing Education Series, Charlottesville, VA; Association for Investment Management \& Research. 
15 HSBC (1994) "Bear Markets and Corrections", Global Investment Strategy, London: HSBC James Capel.

16 JEGADEESH, N. \& TITMAN, S. (1993) "Returns to Buying Winners and Selling Losers: Implications for Stock Market Efficiency" Journal of Finance, 48(1): 65-91,

17 KAO, D.L. \& SHUMAKER, R.D. (1999) "Equity Style Timing", Financial Analysts Journal, Vol. 55(1): 37-47.

18 KAPLANIS, C.E. \& SCHAEFER, S. (1988) "Exchange Risk and International Diversification in Bond and Equity Portfolios", Working paper, London: London Business School.

19 KLEMKOSKY, R.C. (1973) "The Bias in Composite Performance Measures", Journal of Financial \& Quantitative Analysis, 8(3): 505-14.

20 MALKIEL, B.G. (1993) "Returns from Investing in Equity Mutual Funds 1971-1991", Working paper, No. 15, Center for Economic Policy Studies: Princeton University.

21 MITCHELL, E.C. Jr. (1995) Stock Valuation and Selection: A Value Investor's Perspective in: Squires, J.R. (ed.) "Value and Growth Styles in Equity Investing", ICFA Continuing Education Series, Charlottesville, VA: Association for Investment Management \& Research.

22 ROLL, R. (1978) "Ambiguity when performance is Measured by the Securities Market Line", Journal of Finance, 33(4): 1051-69.

23 ROLL, R. (1980) "Performance Evaluation and Benchmark Errors", Journal of Portfolio Management, 6(4): 5-12.

24 ROLL, R. (1981) "Performance Evaluation and Benchmark Errors (II)", Journal of Portfolio Management, 7(2): 17-22.

25 ROSENBERG, B., REID, K. \& LANSTEIN, R. (1985) "Persuasive Evidence of Market Inefficiency", Journal of Finance, 11(3): 9-17.

26 ROSENBERG, C.N. Jr. (1995) "Growth Stock Investing Today" in Squires, J.R. (ed.) Value and Growth Styles in Equity Investing, ICFA Continuing Education Series, Charlottesville, VA: Association for Investment Management \& Research.

27 SANDERS, L.A. (1995) "The Advantage to Value Investing" in Squires, J.R. (ed.) Value and Growth Styles in Equity Investing, ICFA Continuing Education Series, Charlottesville, VA: Association for Investment Management \& Research.

28 SHARPE, W. (1992) "Asset Allocation: Management Style and Performance Measurement" Journal of Porffolio Management, 18(4): 725.

29 SOLNIK, B. (1988) International Investments, Reading, Mass: AddisonWesley.

30 TRITTIN, D.J. (1994) "Value Tilts - Why the Free Lunch and the Active Management Enigma?" Unpublished Research Report, New York: Frank Russell Company. 
31 UMSTEAD, D. (1988) "Weighing the Options: Market-Weight Open to One-Country Domination" Pensions and Investment Age, 13(5): 13-29.

32 WESTERVELT, B.D. \& SCHWAB, T.J. (1995) "Basic Issues and Key Elements for Equity Style Management” in Klein, R.A. \& Lederman, J. (eds.) Equity Style Management: Evaluating and Selecting Investment Styles, Burr Ridge, IL: Irwin Professional Publishing. 